\title{
Radiant Ignition of Polyurethane Foam: The Effect of Sample Size
}

\author{
Rory Hadden, Abubakar Alkatib, Guillermo Rein and José L. Torero, School of \\ Engineering, University of Edinburgh, Edinburgh, $U K$ \\ Guillermo Rein*, Department of Mechanical Engineering, Imperial College \\ London, London, UK
}

Received: 7 July 2010/Accepted: 14 March 2012

\begin{abstract}
Although smouldering ignition of upholstery items remains a leading cause of residential fire deaths, relatively little research is conducted on the topic. An experimental investigation of the effect of sample size on the ignition and spread of smouldering and flaming in polyurethane foam under natural flow conditions is reported here. Polyurethane foam samples are used because this is a common material in modern, residential environments and one for which there exists significant quantities of previous experimental data in the literature. Samples of different square cross-section size and a fixed height of $150 \mathrm{~mm}$ are insulated on all sides except the top which is exposed to a radiant heat flux and is open to the air. Samples with side lengths of $50 \mathrm{~mm}, 100 \mathrm{~mm}$, and $140 \mathrm{~mm}$ are studied. Ignition and spread dynamics are diagnosed using thirteen thermocouples located along the vertical centre line. The onset of smouldering ignition $\left(13 \mathrm{~kW} \mathrm{~m}^{-2}, 8 \mathrm{~kW} \mathrm{~m}^{-2}\right.$ and $7 \mathrm{~kW} \mathrm{~m}^{-2}$ for $50 \mathrm{~mm}$, $100 \mathrm{~mm}$ and $140 \mathrm{~mm}$ sample sizes respectively) is observed at significantly lower heat fluxes that flaming $\left(45 \mathrm{~kW} \mathrm{~m}^{-2}, 32 \mathrm{~kW} \mathrm{~m}^{-2}\right.$ and $30 \mathrm{~kW} \mathrm{~m}^{-2}$ respectively). Critical heat fluxes for smouldering and flaming ignition increase with decreasing sample size, with smouldering ignition being significantly more sensitive to sample size than flaming ignition under the size range studied. Smouldering spread rates are measured in the range from $3 \mathrm{~mm} \mathrm{~min}^{-1}$ to $25 \mathrm{~mm} \mathrm{~min}^{-1}$ and found to be a strong function of the heat flux and depth of the smoulder front. The effect of sample size on smouldering has been theoretically proposed before but this is the first time that this effect has been demonstrated experimentally for ignition. The fact that large samples result in the lowest critical heat flux could have implications for testing procedures and translation of results from small-scale testing to real-scale in the built environment.
\end{abstract}

Keywords: Ignition, Sample size, Smouldering, Transition to flaming, Cone calorimeter, Smoulder propagation

\section{Introduction}

Previous work on smouldering ignition of polyurethane (PU) foam has focused on the effects of flow through the porous fuel [1-3], enhanced or reduced oxygen concentration [4] and the heat flux and exposure time [5]. In this work we present the

\footnotetext{
* Correspondence should be addressed to: Guillermo Rein, E-mail: g.rein@imperial.ac.uk
} 
effect of sample size on the ignition and spread of smouldering under atmospheric oxygen concentrations and natural flow conditions.

Smouldering is a slow, low-temperature, heterogeneous form of combustion in which oxygen directly attacks the surface of a solid fuel [6-8]. Ignition is governed by the balance between heat flux applied to the surface, heat losses and fuel kinetics $[6,8]$, while the self-sustained propagation is governed primarily by the oxygen supply to, and heat losses from the reaction front [8-10]. The heat losses are a function of surface area of the front, and the heat released from the reaction depends on the volume of the reaction front; therefore, smouldering combustion is sensitive to the size of the sample $[1,2,8]$. This work aims to experimentally identify the effect of size on the ignition and subsequent propagation of smouldering and flaming in PU foam over a wide range of heat fluxes using three sample sizes.

The effect of sample size on the smouldering ignition of dusts has been studied by Krause and Schmidt [11, 12] and Schmidt et al. [13]. These investigations used hot particles [11] or elevated ambient temperatures [12,13] to initiate the smouldering reaction. Ignition of larger sample sizes is found to require lower critical ambient temperatures than smaller sizes due to the reduced heat losses from the reaction front. However, larger sample sizes result in lower temperatures and slower propagation of the smouldering front during the reaction. This is attributed to lower rates of oxygen diffusion through the sample to the reaction zone. Schartel et al. [14, 15] studied the effect of sample thickness on flaming ignition of polymers and show that the ignition delay time is reduced and peak heat release rate is increased for thermally thin samples compared to thick samples. These studies did not address smouldering ignition nor the effect of sample area. Ritchie et al. [16] studied the effect of sample area on the heat release from flaming wood. They found that, other than the initial peak, the heat release rate is nearly independent of the sample area. They did not study the effect of size on the critical heat flux for ignition nor smouldering combustion.

The theoretical critical minimum size for sustained smoulder propagation in which the heat losses are balanced by heat generation under conditions of forced flow and no gravity is given by Equation 1 [8],

$$
L_{c}=\frac{4 \delta}{Q_{\mathrm{sml}}} \frac{U_{\mathrm{loss}}\left(T_{\mathrm{sml}}-T_{0}\right)}{\dot{m}^{\prime \prime}},
$$

where $L_{c}$ is the critical length of the sample (side length for a square cross section or diameter of a circular cross section), $\delta$ is the thickness of the smouldering front, $Q_{\mathrm{sml}}$ is the heat of reaction by smouldering, $U_{\text {loss }}$ is the global heat loss coefficient, $T_{\mathrm{sml}}$ is the smouldering temperature, $T_{0}$ is the ambient temperature and $\dot{m}^{\prime \prime}$ is the mass flux of oxidizer to the reaction zone.

Using typical experimental data for smouldering PU foam with forced oxidizer flow $\quad\left(\delta=0.04 \mathrm{~m}, Q_{\text {sml }}=5880 \mathrm{~kJ} / \mathrm{kg}-\mathrm{O}_{2}, U_{\text {loss }}=14 \mathrm{~W} \mathrm{~m}^{-1} \mathrm{~K}^{-1}, T_{\mathrm{sml}}=450^{\circ} \mathrm{C} \quad\right.$ and $T_{0}=20^{\circ} \mathrm{C}$ ) [1, 2], a minimum sample size on the order of $160 \mathrm{~mm}$ is found to be required to sustain smouldering propagation [8]. Equation 1 is only valid for forced flow through the PU foam; however, the scenarios of most importance in fire safety occur under natural flow conditions. In these situations, Equation 1 
cannot be applied and it is necessary to study experimentally the critical size problem under natural flow conditions.

Polyurethane foam can undergo smouldering and flaming combustion. At low heat fluxes, a smouldering reaction will be initiated and will propagate through the sample; at higher heat fluxes, flaming ignition will occur. There are two possible mechanisms which may lead to flaming: either transition from a smouldering reaction or auto-ignition in the gas phase. Transition is a complex phenomenon which, though significant in fire safety, has received relatively little study. Putzeys et al. [17] found that the smoulder velocity and peak temperature are strongly correlated to the occurrence of transition from smouldering to flaming. The transition has also been observed to occur when pores are formed in the region behind the smouldering front [18]. This implies that the smouldering front acts as the source of combustible vapours and heat for the flaming ignition. As a result, the onset of flaming ignition may also be affected by the sample size. Flaming ignition may also occur due to spontaneous ignition of the fuel vapours. This requires that the mixture of vapours and air is heated to a temperature sufficient to initiate a gas-phase reaction [7].

\section{Experimental Set-Up}

The experimental set-up used for these experiments (shown in Figure 1) was based on that of Anderson et al. [5], and not dissimilar to that used by Gratkowski et al. [19]. The set-up is deliberately based on the cone calorimeter, except that there is no gas analysis and the sample depth is increased to $150 \mathrm{~mm}$. A calibrated cone heater provided a uniform heat flux up to $50 \mathrm{~kW} \mathrm{~m}^{-2}$ over the free surface of the sample. The sample was held in a stainless steel sample holder which was inlaid with insulation board to minimize heat losses as well as prevent ingress of

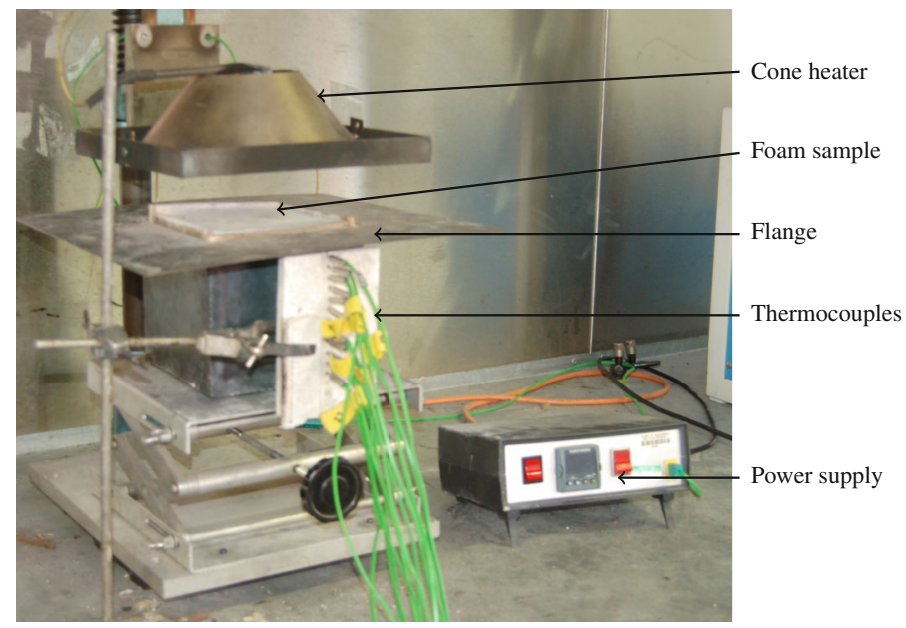

Figure 1. The experimental apparatus. 
oxygen from any face other than the heated free surface. The bottom of the sample holder was not inlaid with insulation. As a result, oxygen could only diffuse downward from the free surface. In order to minimize the formation of recirculation eddies induced by the buoyant flows generated by the heater, a $100 \mathrm{~mm}$ wide flange was added to the top of the sample holder.

Samples of PU foam with square cross sections of length $50 \mathrm{~mm}, 100 \mathrm{~mm}$ and $140 \mathrm{~mm}$ were tested. The depth of all samples was $150 \mathrm{~mm}$. The largest sample was $140 \mathrm{~mm}$ long as this is maximum size that can fit under the cone heater and still be subject to a uniform heat flux across the entire surface. The total error in the heat flux measurement was calculated to be $\pm 0.5 \mathrm{~kW} \mathrm{~m}^{-2}$, due to the positioning of the heat flux meter and the sample being accurate within $\pm 5 \mathrm{~mm}$. This is in addition to a $3 \%$ uncertainty of the meter calibration.

Heat flux along the radius from the sample centre was measured and a maximum reduction of $30 \%$ of the centreline value was found at the edge of the $140 \mathrm{~mm}$ sample. However, because ignition occurs at the centre of the sample where the heat flux is greatest and heat losses are minimum, this variation in heat flux was not expected to have a significant impact on the results. The vertical separation between the heater and the sample was fixed at $25 \mathrm{~mm}$.

The foam samples were instrumented with thirteen sheathed K-type thermocouples of $1.5 \mathrm{~mm}$ diameter. These entered the sample perpendicular to the applied heat flux and were located on the central axis, starting $5 \mathrm{~mm}$ below the exposed surface, and subsequently at $10 \mathrm{~mm}$ intervals to a depth of $125 \mathrm{~mm}$. Thermocouples were held in place using a vertical stand with holes at locations corresponding to the measurement points on the sample. Temperature data were recorded every second using an Agilent 34980A Multifunction Switch interfacing with a computer running Matlab 2008b. Visual observations and temperature measurements allowed the differentiation between no ignition, smouldering ignition and flaming ignition.

A commercially available PU foam sourced from the UK was used. The density was in the range $20-22 \mathrm{~kg} \mathrm{~m}^{-3}$. The foam is the same as that used by Bustamante et al. [20] who found the elemental composition to be $61.9 \%$ carbon, $22.5 \%$ oxygen, $8.5 \%$ hydrogen and $5.9 \%$ nitrogen with trace quantities of sulphur and chlorine. Based on this composition, the overall chemical formula is $\mathrm{CH}_{1.53} \mathrm{O}_{0.27} \mathrm{~N}_{0.08}$.

Prepared samples were placed under the heater and initially shielded from the heat flux using fibreboard insulation. When the heater had reached the temperature corresponding to the desired heat flux at the sample surface, the fibreboard was rapidly removed exposing the sample to the heat flux. No pilot flame or sparking device was used in the set-up.

The critical heat flux required for smouldering and flaming ignitions was found using a systematic, iterative, bisection method. The samples were exposed to a heat flux and, if (flaming or smouldering) ignition occurred, a lower heat flux was selected and a new sample tested. If no ignition occurred, a higher heat flux was used. This method allows the fastest determination of the critical heat flux for ignition. Once the critical heat fluxes for flaming and smouldering ignition had been found, the ignition behaviour at heat fluxes between the two critical heat fluxes and up to $50 \mathrm{~kW} \mathrm{~m}^{-2}$ was studied. The number of experiments carried out 


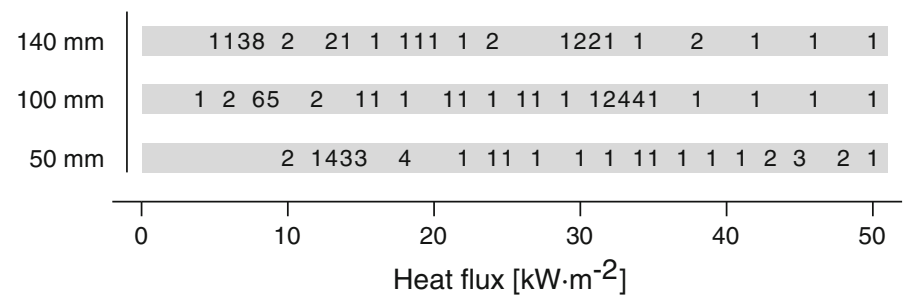

Figure 2. Test matrix showing the heat fluxes at which each sample size was tested. The one-digit numbers indicate how often each experiment was undertaken.

for each heat flux and sample size are shown in Figure 2. The experiment was terminated if no ignition was observed after $30 \mathrm{~min}$ or when the thermocouple traces reached steady state conditions.

\section{Results}

Figure 3 shows samples before and after testing. As the heat flux is increased and the combustion becomes stronger, the samples become increasingly destroyed. These images provide qualitative evidence of the combustion processes taking place which is augmented by detailed temperature measurements.

Temperature data measured in the samples are used to distinguish the different types of ignition upon exposure of the sample to a heat flux. The types of ignition are classified as follows: no ignition, partial smoulder, complete smoulder and flaming ignition. Peak temperatures for smouldering were typically in the range $300^{\circ} \mathrm{C}$ to $400^{\circ} \mathrm{C}$, while peak temperatures measured during flaming were $600^{\circ} \mathrm{C}$ to $700^{\circ} \mathrm{C}$, except in the case of the $50 \mathrm{~mm}$ samples when flaming was visually

(a)

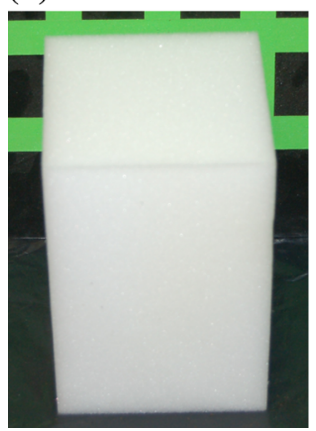

(b)

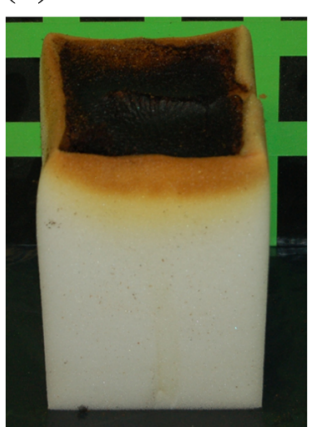

(c)

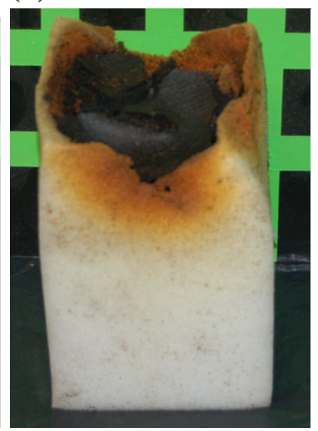

(d)

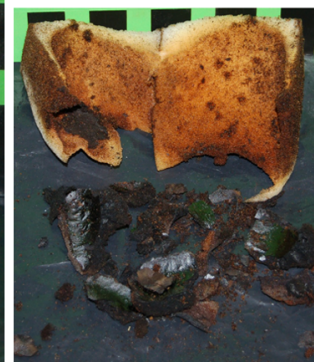

Figure 3. Images of $100 \mathrm{~mm}$ samples showing (a) virgin foam, (b) charred foam in which a smoulder front did not propagate, (c) a sample in which smouldering occurred and (d) a sample which underwent flaming ignition. 

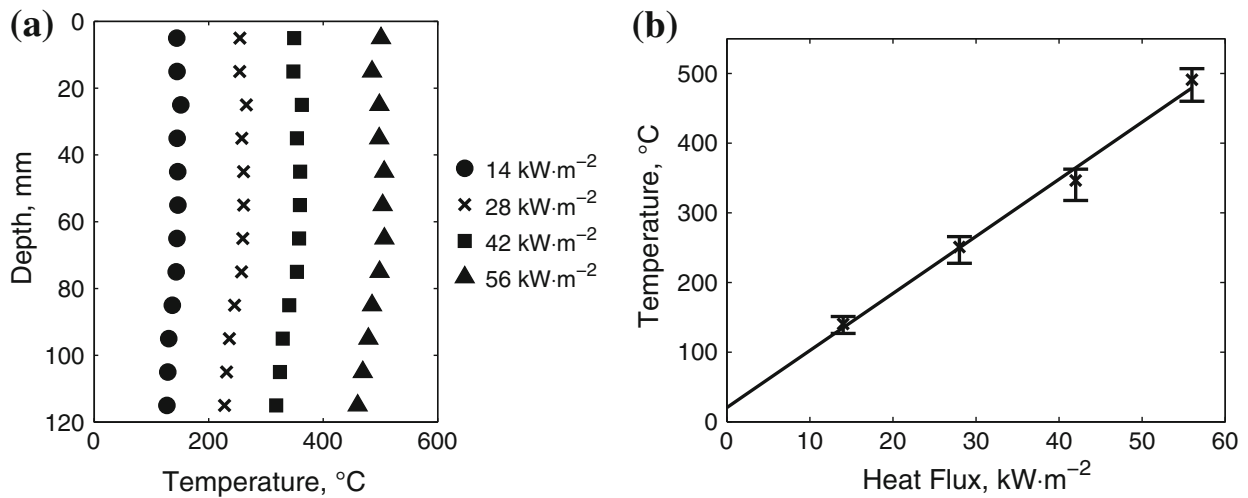

\section{Figure 4. (a) Steady state temperature profiles of exposed thermo- couples without the foam sample for four heat fluxes and (b) relation- ship of heat flux and temperature. The marker is the mean and the error bars relate to the maximum and minimum measured values.}

observed but temperatures in the sample remained around $350^{\circ} \mathrm{C}$ to $450^{\circ} \mathrm{C}$. After the combustion was complete, the thermocouples were allowed to reach steady state before the experiment was terminated.

The reference temperature profiles measured in the apparatus for $100 \mathrm{~mm}$ size set-up without a foam sample inside at heat fluxes of $14 \mathrm{~kW} \mathrm{~m}^{-2}, 28 \mathrm{~kW} \mathrm{~m}^{-2}$, $44 \mathrm{~kW} \mathrm{~m}^{-2}$ and $56 \mathrm{~kW} \mathrm{~m}^{-2}$ are shown in Figure $4 \mathrm{a}$. As the heat flux is increased, the steady state temperatures reached by the thermocouples increases linearly. Temperatures are uniform up to a depth of $65 \mathrm{~mm}$ after which the temperature begins to decrease slightly. Figure $4 \mathrm{~b}$ shows that mean steady state reference temperature scales linearly with applied heat flux. Error bars indicate the maximum and minimum recorded temperatures. If the thermocouples exceed the steady state temperatures given by this analysis during an experiment, it can be assumed that there is a significant exothermic reaction occurring. Therefore, these are presented as a reference to identify in the temperature profiles when and where combustion is occurring. Note that temperatures behind the combustion front may remain high because the thermocouples are heated by the smouldering front and insulated by the residue char, which prevents them from cooling to ambient temperature.

The temperature data discussed in the following sections are presented in two ways. The first is an analysis of the temperature-time series, showing the temperature evolution at each thermocouple in the sample over the time of the experiment. This allows the progress of the combustion reaction over time to be assessed. The second is an analysis of the temperature profile through the sample depth at three or four different times during the reaction. These times are chosen to be just after exposure to the heat flux, during combustion and during the final steady state period. This method allows us to see the propagation of a heat wave through the sample. The error in the measurements is given as the mean error for all experiments where repeats were carried out. This was calculated to be $17 \%$ for the temperatures. 


\section{1. $50 \mathrm{~mm}$ Samples}

Figure 5 shows temperature data for four experiments at heat fluxes $10 \mathrm{~kW} \mathrm{~m}{ }^{-2}$, $18 \mathrm{~kW} \mathrm{~m}^{-2}, 37 \mathrm{~kW} \mathrm{~m}^{-2}$ and $39 \mathrm{~kW} \mathrm{~m}^{-2}$. After $40 \mathrm{~min}$, exposure to a heat flux of $10 \mathrm{~kW} \mathrm{~m}^{-2}$ did not lead to ignition of the foam and only in-depth conduction was observed with no exothermic or endothermic reactions taking place (Figure 5a). The temperature profile shown in Figure 5b shows that the temperature throughout the sample increases in time with the maximum temperature always observed at the free surface. The temperature decreases with depth, as expected in an inert solid. The maximum observed temperature was $275^{\circ} \mathrm{C}$.

A heat flux of $18 \mathrm{~kW} \mathrm{~m}^{-2}$ (Figure $5 \mathrm{c}$ and $5 \mathrm{~d}$ ) shows the onset of smouldering at $3 \mathrm{~min}$ to $4 \mathrm{~min}$. This is shown in the temperature profiles as an increase in temperature at depths of $25 \mathrm{~mm}$ and $35 \mathrm{~mm}$ at 5 min compared to the temperature at $15 \mathrm{~mm}$. The maximum temperature is $337^{\circ} \mathrm{C}$.

A stronger smouldering reaction was observed upon exposure to a heat flux of $37 \mathrm{~kW} \mathrm{~m}^{-2}$ (Figure 5e). The temperature profile Figure $5 \mathrm{f}$ shows that after $5 \mathrm{~min}$ of exposure, the front has spread to a depth of $65 \mathrm{~mm}$ and shows a significant temperature gradient between $65 \mathrm{~mm}$ and $85 \mathrm{~mm}$. The maximum observed temperature was $461^{\circ} \mathrm{C}$.

Figure 5g shows an experiment where a higher heat flux $\left(39 \mathrm{~kW} \mathrm{~m}^{-2}\right)$ resulted in flaming and more extensive consumption of the foam, allowing the thermocouples above the flame to measure the temperature of the hot gases (up to $700^{\circ} \mathrm{C}$ ). The flaming did not propagate through the sample and the reaction was quenched at around $105 \mathrm{~mm}$ (Figure $5 \mathrm{~h}$ ). The temperature profile shows that there is rapid propagation through the sample and after $1 \mathrm{~min}$, heat has reached the thermocouple $55 \mathrm{~mm}$ from the free surface.

\section{2. $100 \mathrm{~mm}$ Samples}

Figure 6 shows temperature traces for experiments at four heat fluxes $8 \mathrm{~kW} \mathrm{~m}^{-2}$, $8.3 \mathrm{~kW} \mathrm{~m}^{-2}, 32.5 \mathrm{~kW} \mathrm{~m}^{-2}$ and $33 \mathrm{~kW} \mathrm{~m}^{-2}$. No ignition was observed at a heat flux of $8 \mathrm{~kW} \mathrm{~m}^{-2}$ (Figure 6a). The peak in the thermocouple near the surface at about 4 min $\left(298^{\circ} \mathrm{C}\right)$ was due to degradation of the foam at the surface and exposure of the thermocouple directly to the radiant heat. This is observed in Figure $6 \mathrm{~b}$ where at $15 \mathrm{~min}$ the peak temperature is seen at the thermocouple $15 \mathrm{~mm}$ below the surface.

Partial smoulder ignition at a heat flux of $8.3 \mathrm{~kW} \mathrm{~m}^{-2}$ propagated approximately $55 \mathrm{~mm}$ into the sample after $20 \mathrm{~min}$ of heating (Figure 6c). Temperatures exceed $300^{\circ} \mathrm{C}$ for a significant time as the smoulder front propagates through the sample. The maximum temperature is $377^{\circ} \mathrm{C}$ at a depth of $15 \mathrm{~mm}$. The propagation can be seen in Figure $6 \mathrm{~d}$ as the peak temperature moved from $15 \mathrm{~mm}$ at $8 \mathrm{~min}$ to $25 \mathrm{~mm}$ after $15 \mathrm{~min}$.

A heat flux of $32.5 \mathrm{~kW} \mathrm{~m}^{-2}$ (Figure 6e) results in complete smoulder of the sample enhanced by the higher heat flux. The temperature behind the smouldering front is $250^{\circ} \mathrm{C}$ to $305^{\circ} \mathrm{C}$, compared to $75^{\circ} \mathrm{C}$ to $275^{\circ} \mathrm{C}$ in Figure 6c. The front propagated from $15 \mathrm{~mm}$ to $65 \mathrm{~mm}$ between $1 \mathrm{~min}$ and $3 \mathrm{~min}$ after exposure. The final steady state temperatures are around $300^{\circ} \mathrm{C}$ as shown in Figure $6 \mathrm{f}$. 

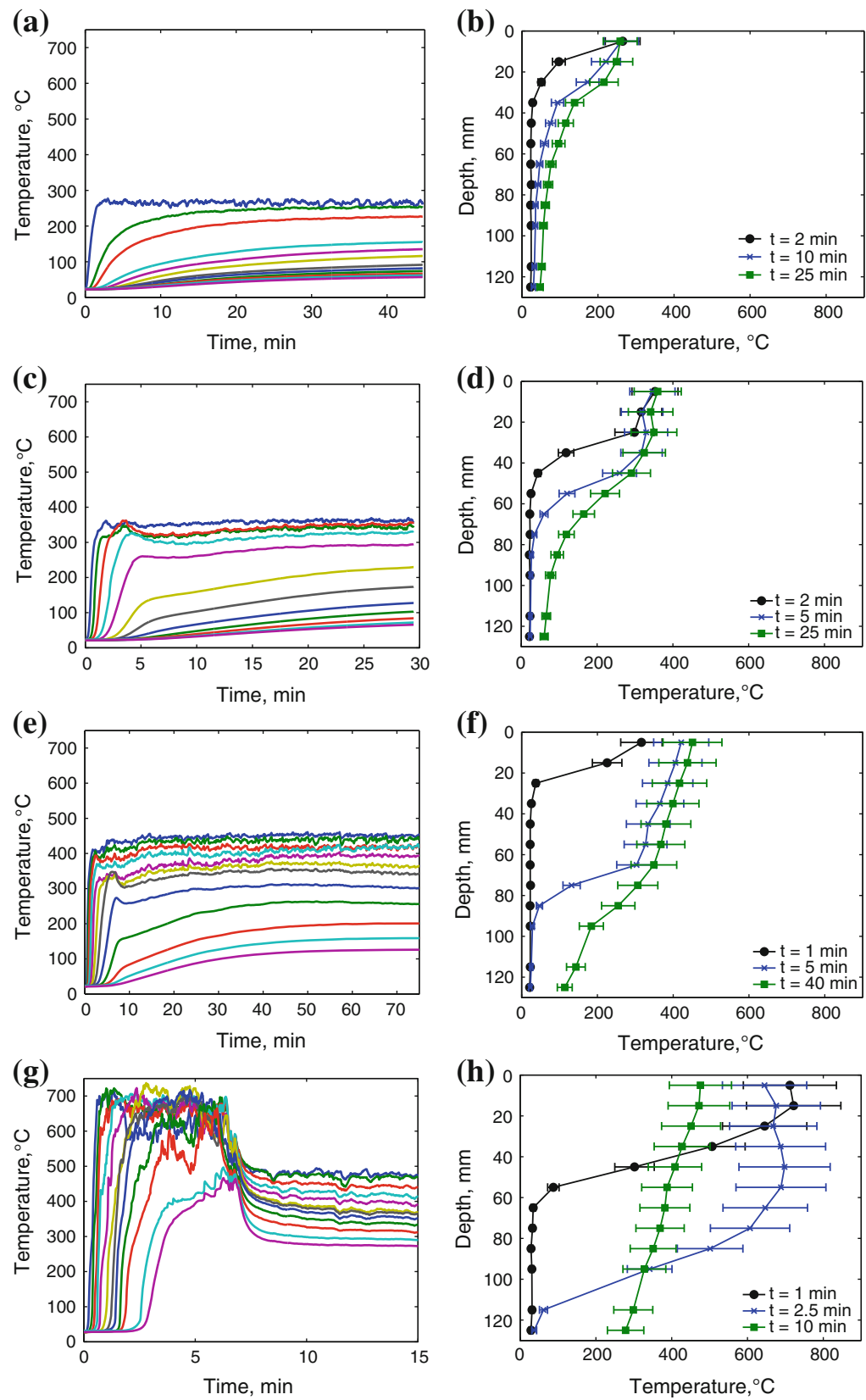

Figure 5. Temperature traces and vertical profiles for selected experiments on $50 \mathrm{~mm}$ sample (a, b) $10 \mathrm{~kW} \mathrm{~m}^{-2}$, (c, d) $18 \mathrm{~kW} \mathrm{~m}^{-2}$, $(e, f) 37.3 \mathrm{~kW} \mathrm{~m}^{-2},(\mathrm{~g}, \mathrm{~h}) 39 \mathrm{~kW} \mathrm{~m}^{-2}$. In the left column, the leftmost line corresponds to temperature $5 \mathrm{~mm}$ beneath the surface. Moving right, the lines represent depths increasing by $10 \mathrm{~mm}$ up to $125 \mathrm{~mm}$. 

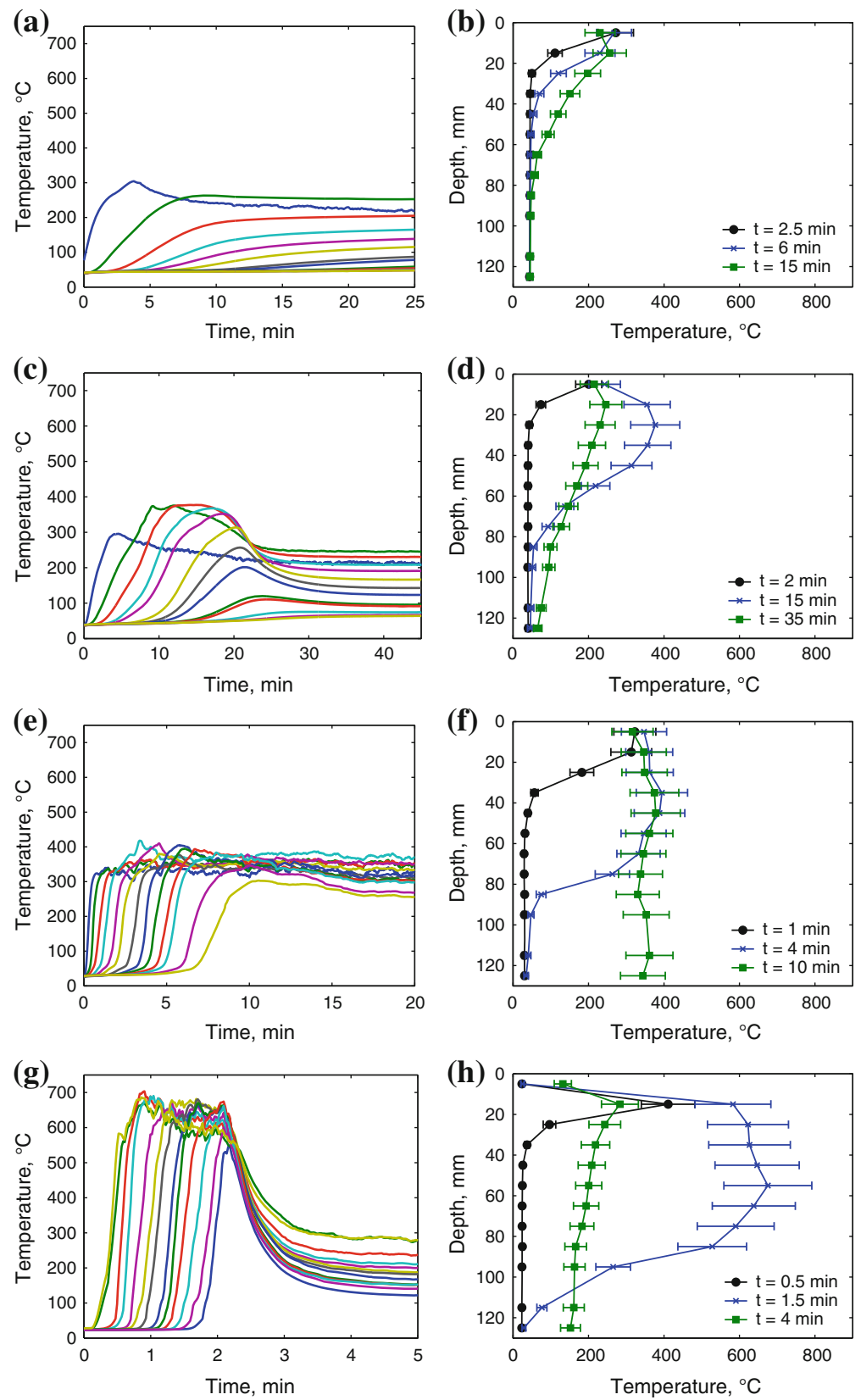

Figure 6. Temperature traces and vertical profiles for selected experiments using $100 \mathrm{~mm}$ sample (a, b) $8 \mathrm{~kW} \mathrm{~m}^{-2}$, (c, d) $8.3 \mathrm{~kW} \mathrm{~m}^{-2}$, $(e, f) 32.5 \mathrm{~kW} \mathrm{~m}^{-2},(\mathrm{~g}, \mathrm{~h}) 34.6 \mathrm{~kW} \mathrm{~m}^{-2}$. Distance form the surface increases from left to right. In the left column, the leftmost line is the temperature at the thermocouple $5 \mathrm{~mm}$ below the surface increasing in depth at $10 \mathrm{~mm}$ intervals to $125 \mathrm{~mm}$. 
Flaming ignition is seen at a heat flux of $34.6 \mathrm{~kW} \mathrm{~m}^{-2}$ (Figure $6 \mathrm{~g}$ ), where the maximum temperature is $715^{\circ} \mathrm{C}$. Figure $6 \mathrm{~h}$ shows the rapid spread through the foam and steady state temperatures lower than those observed for the complete smoulder case. This is because the foam surrounding the thermocouples has been consumed by the flame, exposing them to increased heat losses. After flaming ignition, the front propagated through the sample in $2.5 \mathrm{~min}$ compared to $20 \mathrm{~min}$ for smouldering.

\section{3. $140 \mathrm{~mm}$ Samples}

Figure $7 \mathrm{a}$ and $7 \mathrm{~b}$ show an experiment at a heat flux of $7.3 \mathrm{~kW} \mathrm{~m}^{-2}$ in which no smouldering occurred. Smouldering is observed at $7.8 \mathrm{~kW} \mathrm{~m}^{-2}$ (Figure 7c) with ignition occurring after $10 \mathrm{~min}$ exposure. The maximum temperature was $398^{\circ} \mathrm{C}$. The smoulder front propagated to $55 \mathrm{~mm}$ at $22 \mathrm{~min}$ after exposure as shown in Figure $7 d$.

At $28.8 \mathrm{~kW} \mathrm{~m}^{-2}$, complete smoulder of the sample is observed (Figure 7e) reaching a maximum temperature of $383^{\circ} \mathrm{C}$. The temperature profile Figure $7 \mathrm{f}$ shows propagation of the smoulder front with steep temperature gradients over short distances indicating the position of the hot oxidation and colder pyrolysis fronts. Steady-state temperatures of $275^{\circ} \mathrm{C}$ to $375^{\circ} \mathrm{C}$ are observed.

Flaming ignition is shown in Figure $7 \mathrm{~g}$ for a heat flux of $30.6 \mathrm{~kW} \mathrm{~m}^{-2}$. Rapid propagation is observed in Figure $7 \mathrm{~h}$ with the front moving from a depth of $35 \mathrm{~mm}$ to $85 \mathrm{~mm}$ in $30 \mathrm{~s}$. A maximum temperature of $711^{\circ} \mathrm{C}$ is reached. As in the $100 \mathrm{~mm}$ samples, the thermocouples reach a lower steady state temperature than in the smouldering cases.

\subsection{Summary of Ignition Tests}

Figure 8 shows the number of times at which each sample size was tested at a given heat flux. The shading represents the ignition type with light gray representing no ignition, mid gray representing smouldering ignition and dark gray flaming ignition. We can clearly see that the flaming ignition of the $50 \mathrm{~mm}$ samples is more scattered than the larger samples. We can also see that there is a significant decrease in the critical heat fluxes required for both smouldering and flaming ignition as the sample size is increased. The numbers indicate how many experiments were undertaken at a given heat flux.

\subsection{Critical Heat Flux for Ignition}

Smouldering and flaming ignitions for the three sample sizes were observed visually as well as using the temperature data seen in Figures 5, 6, and 7. The critical heat flux ranges are detailed in Table 1. These results are in agreement with the work of Anderson et al. [5] and Bustamante et al. [20] where comparison is possible, and complement them with new findings and a wider range of conditions.

The trend observed is that as sample size is increased, the critical heat flux for smouldering and flaming ignition is reduced. This is in agreement with the theory that smouldering is significantly influenced by heat losses from the sample sides 
(a)

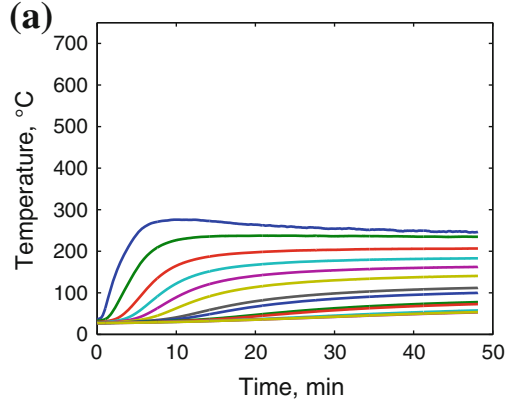

(c)

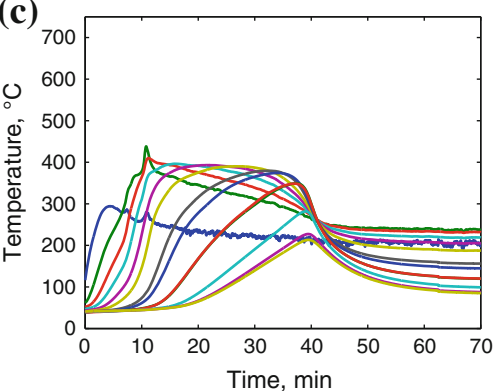

(e)

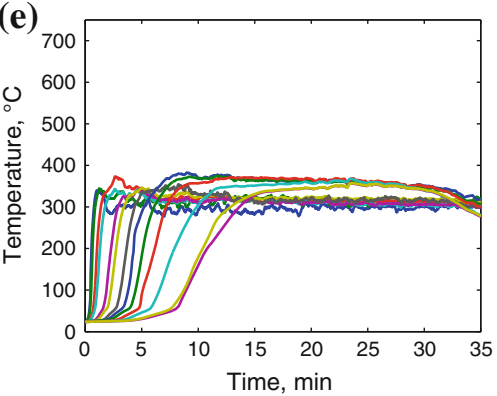

(g)

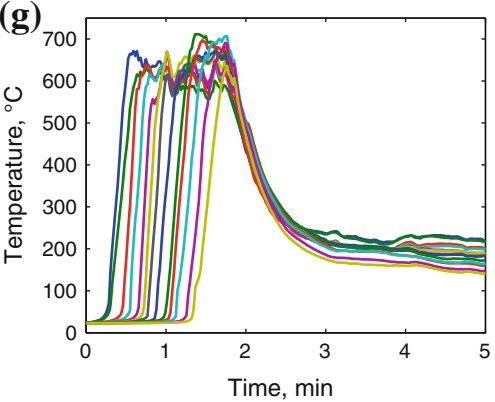

(b)

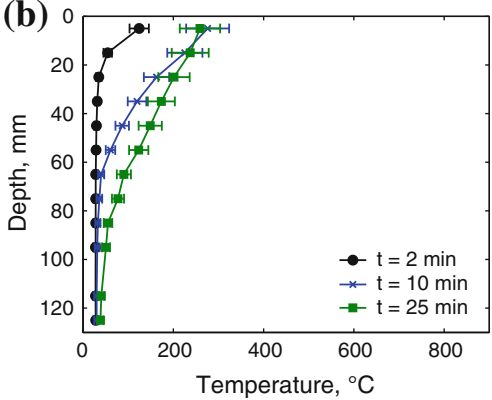

(d)

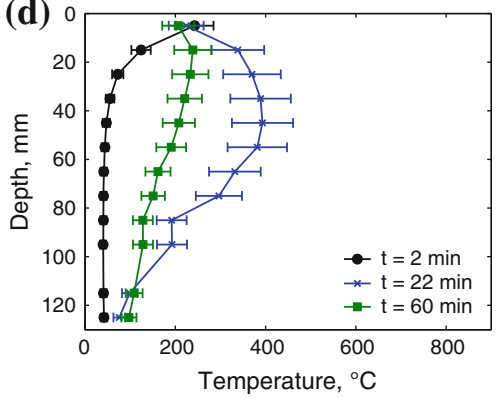

(f)

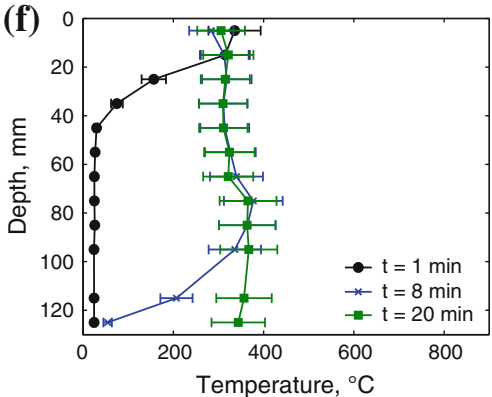

(h)

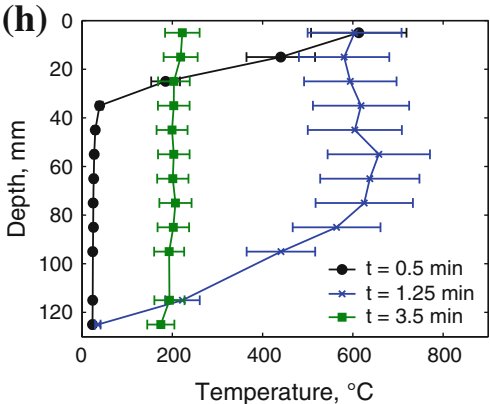

Figure 7. Temperature traces and vertical profiles for selected experiment using $140 \mathrm{~mm}$ samples (a, b) $7.3 \mathrm{~kW} \mathrm{~m}^{-2}$, (c, d) $7.8 \mathrm{~kW} \mathrm{~m}^{-2},(e, f) 28.8 \mathrm{~kW} \mathrm{~m}^{-2},(\mathrm{~g}, \mathrm{~h}) 30.6 \mathrm{~kW} \mathrm{~m}^{-2}$. In the left column, distance form the surface increases from left to right. The leftmost line is the temperature at the thermocouple $5 \mathrm{~mm}$ below the surface increasing in depth at $10 \mathrm{~mm}$ intervals to $125 \mathrm{~mm}$. 


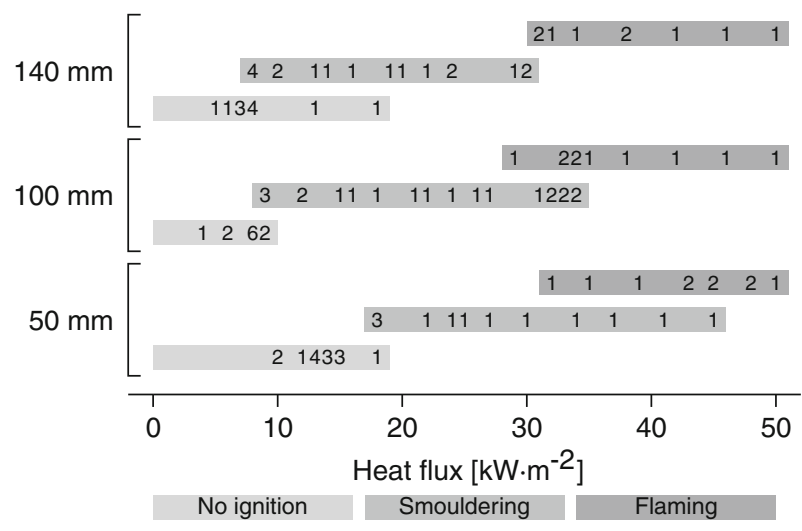

Figure 8. Test matrix showing the heat flux and sample size relationships tested and the resulting ignition types. One-digit numbers indicate how many times samples were tested at the heat flux.

\section{Table 1 \\ Critical Heat Flux for Ignition of the Sample Sizes Studied and Those Found in the Liferature}

\begin{tabular}{lcc}
\hline $\begin{array}{l}\text { Sample size } \\
(\mathrm{mm})\end{array}$ & $\begin{array}{c}\text { Critical heat flux for } \\
\text { smouldering ignition } \\
\left(\mathrm{kW} \mathrm{m}^{-2}\right)\end{array}$ & $\begin{array}{c}\text { Critical heat flux } \\
\text { for flaming ignition } \\
\left(\mathrm{kW} \mathrm{m}^{-2}\right)\end{array}$ \\
\hline 50 & $18-19$ & $32-45$ \\
100 & $8-9$ & $32-37$ \\
140 & $7-8$ & $30-31$ \\
$100[20]$ & $\mathrm{N} / \mathrm{A}$ & 35 \\
$300[5]$ & 6 & $\mathrm{~N} / \mathrm{A}$ \\
\hline
\end{tabular}

and scales with the surface area to volume ratio [8]. The dependence on heat flux seems to be reduced at sizes greater than $140 \mathrm{~mm}$ suggesting that the critical heat flux becomes independent of sample size for large samples.

\subsection{Maximum Temperature and Time to Ignition}

Figure 9 shows the maximum temperatures observed in each experiment. The figure shows three regimes: the first, at low heat fluxes when ignition does not occur, shows a steady increase in maximum temperature with heat flux up to around $300^{\circ} \mathrm{C}$. These cases of no ignition are marked by crosses. As the heat flux is increased, a step in the maximum temperature up to around $400^{\circ} \mathrm{C}$ is observed. This region is represented by circles and corresponds to smouldering ignitions. This step is more pronounced for the $100 \mathrm{~mm}$ and $140 \mathrm{~mm}$ samples than the $50 \mathrm{~mm}$ samples, suggesting a different behaviour for the onset of smouldering at this size. The maximum temperature then increases with heat flux up to approximately 


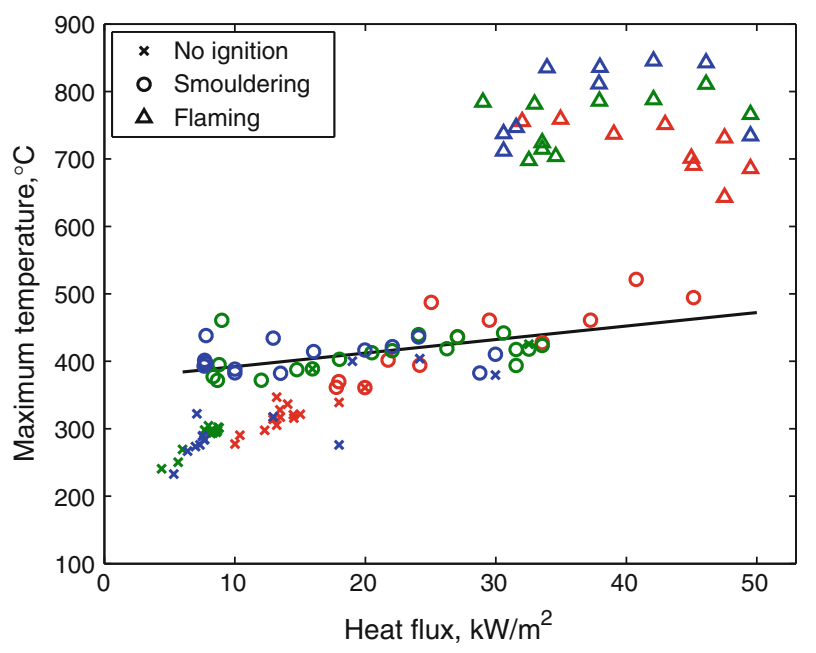

Figure 9. The maximum temperatures observed during experiments. Crosses represent no ignition, circles represent smouldering ignition and triangles represent flaming ignition. Red, green and blue represent $50 \mathrm{~mm}, 100 \mathrm{~mm}$ and $140 \mathrm{~mm}$ samples respectively. We see that in the no ignition cases, the temperature increases with heat flux before there is a step which coincides with the onset of smouldering. There is another step up to temperatures in the region of $700^{\circ} \mathrm{C}$ corresponding to the onset of flaming ignition.

$425^{\circ} \mathrm{C}$ before a second step to temperatures in the region of $700^{\circ} \mathrm{C}$. This corresponds to flaming ignition and is denoted by triangles. The critical heat fluxes found by this analysis are in the ranges in Table 1. This diagnostic validates the definition of $350^{\circ} \mathrm{C}$ as the ignition criterion for smouldering.

The time to ignition for experiments in which smouldering or flaming occurred is shown in Figure 10. The time to ignition was defined when the thermocouple located $25 \mathrm{~mm}$ from the free surface reached $350^{\circ} \mathrm{C}$. This condition was defined a posteriori based on the analysis presented in Figure 9. For smouldering ignitions, time to ignition ranged from $2 \mathrm{~min}$ to $20 \mathrm{~min}$, whereas for flaming this was less than $2 \mathrm{~min}$ and flames were generally visually observed less than $5 \mathrm{~s}$ after exposure to the heat flux.

Figure 10a shows the time to ignition as a function of incident heat flux. It is observed that the time to ignition decreases as the heat flux is increased. For smouldering initiation, at high heat fluxes, the time to ignition decreases significantly to less than $30 \mathrm{~s}$. It is seen that the ignition time of the $50 \mathrm{~mm}$ samples follows a different trend from that of the $100 \mathrm{~mm}$ and $140 \mathrm{~mm}$ samples.

Figure $10 \mathrm{~b}$ shows the inverse of the square root of time to ignition. All samples follow a linear relationship as predicted by classical ignition theory [21] indicating that as the applied heat flux is increased, the time to ignition decreases. This suggests that the processes are driven by heat conduction. Again, the $50 \mathrm{~mm}$ samples appear to follow a different trend from the $100 \mathrm{~mm}$ and $140 \mathrm{~mm}$ samples suggest- 

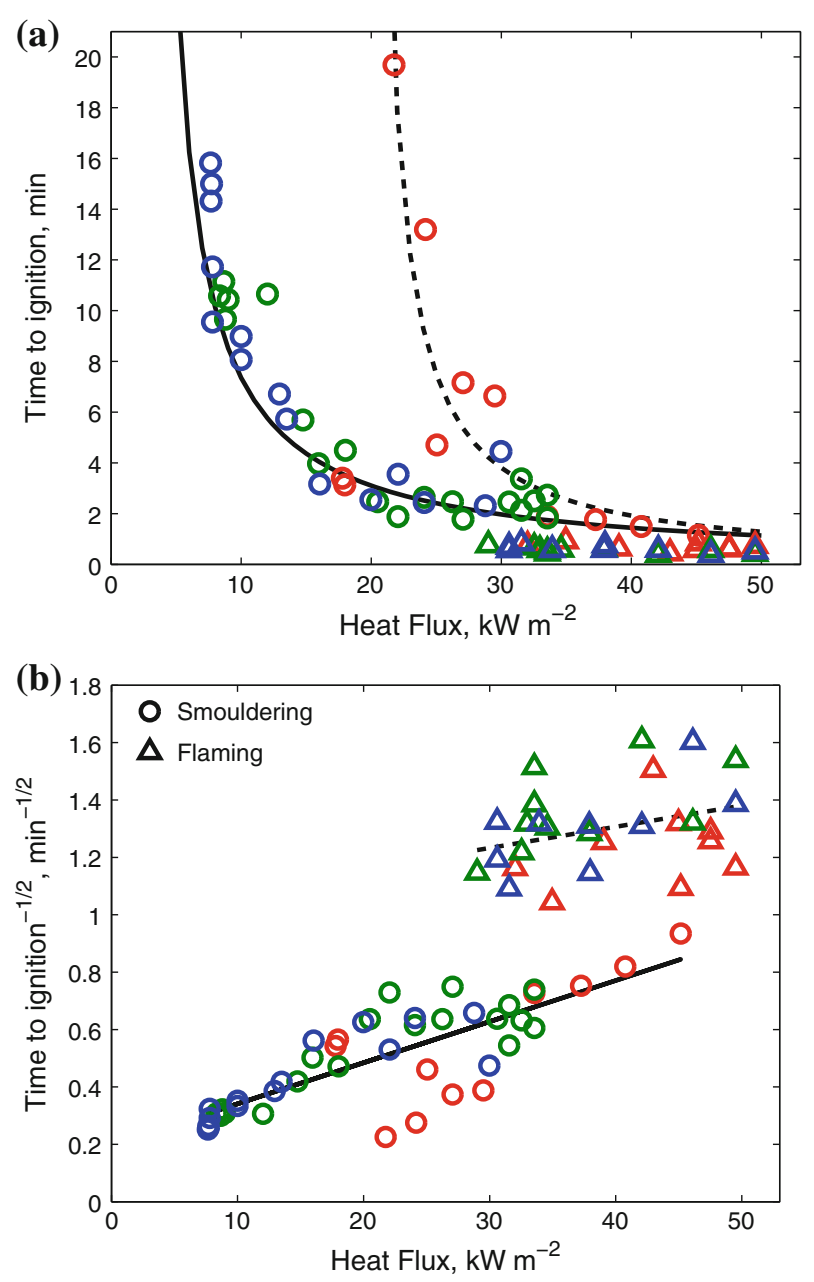

Figure 10. Time to ignition showing (a) asymptotic behaviour and (b) $1 / \sqrt{t_{\text {ig }}}$ for smouldering (circles) and flaming (triangles) samples. Red, green and blue symbols represent $50 \mathrm{~mm}, 100 \mathrm{~mm}$ and $140 \mathrm{~mm}$ sample sizes respectively.

ing that the controlling mechanisms of ignition at that size are different from those for larger samples.

\subsection{Smouldering Spread Rate}

Spread rate was found to be a function of the applied heat flux as shown in Figure 11. Spread rate was calculated between the thermocouples located $25 \mathrm{~mm}$ and $35 \mathrm{~mm}$ below the free surface. This location is chosen because the heat directly transferred from external heat flux is lower than for locations closer to the 


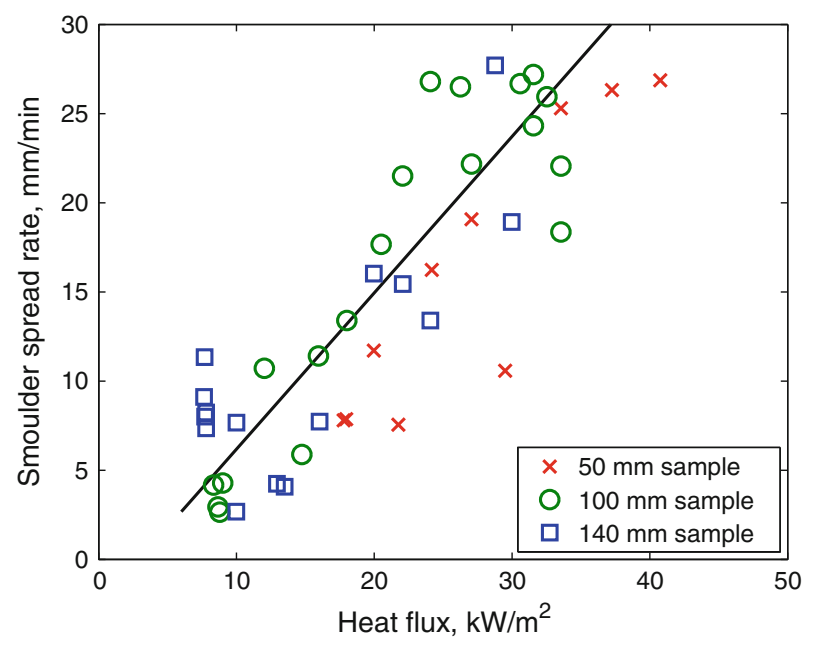

\section{Figure 11. Smoulder spread rate as a function of heat flux measured between depths $25 \mathrm{~mm}$ and $35 \mathrm{~mm}$. Circles are $50 \mathrm{~mm}$ samples, squares $100 \mathrm{~mm}$ samples and triangles $140 \mathrm{~mm}$ samples.}

surface, while still having good oxygen supply from the free surface to allow smouldering propagation.

The smoulder spread rates range from approximately $5 \mathrm{~mm} \mathrm{~min}^{-1}$ to $10 \mathrm{~mm} \mathrm{~min}^{-1}$ for smouldering at heat fluxes just above the critical heat flux and increase up to around $25 \mathrm{~mm} \mathrm{~min}^{-1}$ before the onset of flaming. The error in the spread rate is estimated to be $\pm 25 \%$ due to the uncertainty of $\pm 2.5 \mathrm{~mm}$ in the thermocouple placement in the foam. The spread rates measured for smouldering are in agreement with the work of Anderson et al. [5] using a similar experimental set-up but are higher than those generally found for unassisted smouldering [3, 17]. The higher spread rate could be explained by the energy assistance provided by the heater.

Figure 12 shows the spread rate as a function of depth for smouldering in a $100 \mathrm{~mm}$ sample at heat fluxes of $8 \mathrm{~kW} \mathrm{~m}^{-2}, 26 \mathrm{~kW} \mathrm{~m}^{-2}$ and $33 \mathrm{~kW} \mathrm{~m}^{-2}$. There is a steady increase in smoulder spread rate as the heat flux is increased. The spread rates between $15 \mathrm{~mm}$ and $25 \mathrm{~mm}$ depth are $6 \mathrm{~mm} \mathrm{~min}^{-1}, 18 \mathrm{~mm} \mathrm{~min}^{-1}$ and $22 \mathrm{~mm} \mathrm{~min}^{-1}$ respectively. A strong dependence on depth is seen with spread rates decreasing to $3 \mathrm{~mm} \mathrm{~min}^{-1}, 8 \mathrm{~mm} \mathrm{~min}^{-1}$ and $18 \mathrm{~mm} \mathrm{~min}^{-1}$ at a depth of $50 \mathrm{~mm}$. The spread at $16 \mathrm{~kW} \mathrm{~m}^{-2}$ and $33 \mathrm{~kW} \mathrm{~m}^{-2}$ reaches $95 \mathrm{~mm}$; however, the spread rate has reduced to 4 and $13 \mathrm{~mm} \mathrm{~min}^{-1}$, respectively. The same trend is seen for the $50 \mathrm{~mm}$ and $140 \mathrm{~mm}$ samples; however, for the $50 \mathrm{~mm}$ samples, the maximum spread depth is $75 \mathrm{~mm}$.

It is known that the ignition of smouldering combustion is controlled by heat transfer and kinetics and the spread is controlled by the availability of oxygen and heat losses [6, 8]. Therefore, this decrease could be explained by the decrease in available oxygen as the smoulder propagates deeper into the sample. This means 


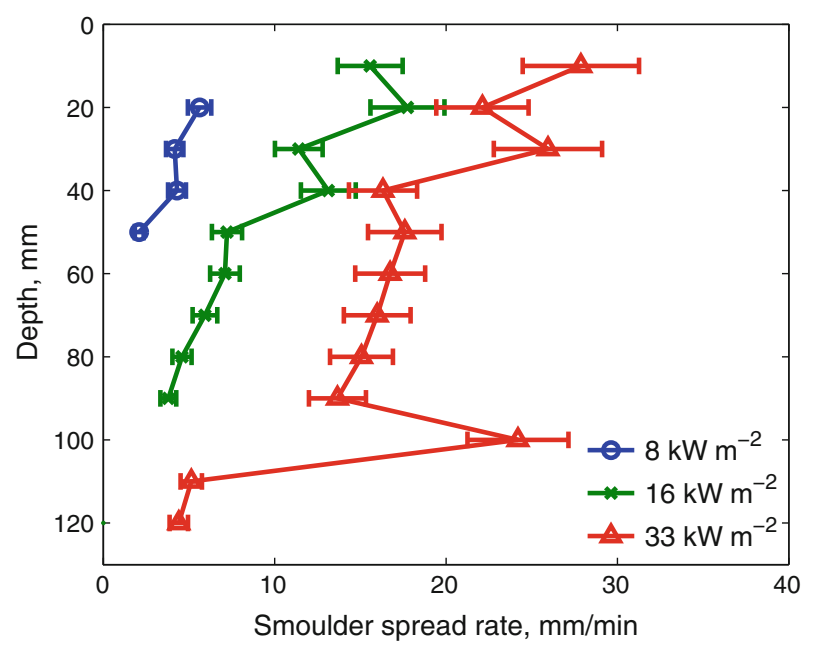

Figure 12. Spread rate of the smouldering front as a function of depth for samples of $100 \mathrm{~mm}$ subject to heat fluxes of between $8 \mathrm{~kW} \mathrm{~m}^{-2}$ and $33 \mathrm{~kW} \mathrm{~m}^{-2}$. Spread rate is seen to increase with heat flux. The error is calculated at $12 \%$ based on the repeatability of experiments.

that oxygen has to diffuse further before it reaches the reaction front and limits the spread rate. This effect has been previously reported by Palmer [22] and Krause and Schmidt [11]. Near the free surface, there is a large supply of oxygen and the reaction is dominated by the heat supplied by the heater.

\section{Discussion}

\subsection{Sample Size}

The sample size has been shown to have a strong impact on the smouldering and flaming ignition of polyurethane foams. The critical heat flux for smouldering and flaming are shown to decrease as the sample size is increased. This relationship appears to become less strong for larger samples. The behavior of the $50 \mathrm{~mm}$ samples is seen to differ significantly from that of the $100 \mathrm{~mm}$ and $140 \mathrm{~mm}$ samples. This could be due either to the small surface area available for oxygen diffusion to the sample which would limit the reaction rate, or increased heat losses to the surroundings for the $50 \mathrm{~mm}$ sample which has a higher surface area to volume ratio than the larger sizes. Unfortunately, it is not possible to conclude further using the data obtained from the current experimental set-up.

\subsection{Transition to Flaming}

The transition between smouldering and flaming ignition is a complex phenomenon marked by rapid changes in spread rate and peak temperatures. There are two possible mechanisms for this transition: gas phase ignition or the transition 
from smouldering to flaming. The gas phase ignition may be due either to autoignition or piloted ignition at the cone heater which, at high heat fluxes, operates at temperatures exceeding $700^{\circ} \mathrm{C}$.

Transition from sustained smoulder to flaming was not observed in any of the experiments. However, it was not possible to conclude on the possible transition from incipient smouldering to flaming.

There are two reasons that the transition from incipient smouldering to flaming would not be observed with the current diagnostics set-up: flaming ignition would take place at a much faster time scale than that required for a smouldering signature to develop in the temperature data, and transition would occur on a thin layer within the foam, which the spatial temperature resolution used here $(10 \mathrm{~mm})$ would be too coarse to capture.

Bustamante et al. [20] found the minimum heat flux for flaming auto-ignition of the same PU foam as used in this work was $35 \mathrm{~kW} \mathrm{~m}^{-2}$ (compared to $9 \mathrm{~kW} \mathrm{~m}^{-2}$ for piloted ignition). These experiments were carried out in the cone calorimeter using samples with square cross section of $100 \times 100 \mathrm{~mm}$ and height of $50 \mathrm{~mm}$. This heat flux for auto-ignition agrees well with the range found here for flaming ignition for the same sample size $\left(32 \mathrm{~kW} \mathrm{~m}^{-2}\right.$ to $\left.37 \mathrm{~kW} \mathrm{~m}^{-2}\right)$. This suggests that the mechanisms leading to flaming ignition in [20] are the same as the mechanisms in this work. Bustamante et al. concluded that flaming ignition was an auto-ignition process but did not consider smouldering and transition to flaming as a possible mechanism, or the hot surfaces of the cone acting as a pilot.

Putzeys et al. [17] found that a minimum heat flux between $8 \mathrm{~kW} \mathrm{~m}^{-2}$ and $8.75 \mathrm{~kW} \mathrm{~m}^{-2}$ will result in the transition from smouldering to flaming of a $50 \mathrm{~mm} \times 50 \mathrm{~mm} \times 125 \mathrm{~mm}$ sample of PU foam with internal forced flow and sample sides heated to $200^{\circ} \mathrm{C}$ by external means. This value is much lower than that measured here for $50 \mathrm{~mm}$ size $\left(45 \mathrm{~kW} \mathrm{~m}^{-2}\right.$ to $\left.48 \mathrm{~kW} \mathrm{~m}^{-2}\right)$, but the heating of the samples in [7] sides and the increased air flow dramatically enhance the smouldering combustion, increasing the likelihood of transition to flaming.

Using the temperature data collected and comparing the tests here to those available in the literature, it is not possible to provide a definite mechanism for flaming ignition. Further investigations using enhanced apparatus such as higher thermocouple resolution to capture the smoulder reaction in more detail, gas analysis, high speed cameras, advanced flame detection techniques or changing the separation between the sample and the cone heater but keeping the heat flux constant could assist in the determination of the process leading to flaming ignition.

\section{Conclusions}

The effect of sample size on radiant smouldering ignition had been theoretically proposed before but this is the first time that it is demonstrated experimentally. The onset of smouldering ignition was observed in the ranges $13-14 \mathrm{~kW} \mathrm{~m}$, 8-9 $\mathrm{kW} \mathrm{m}{ }^{2}, 7-8 \mathrm{~kW} \mathrm{~m}^{2}$ for $50 \mathrm{~mm}, 100 \mathrm{~mm}$ and $140 \mathrm{~mm}$ sample sizes respectively. The onset of flaming ignition was observed in the ranges $45-48 \mathrm{~kW} \mathrm{~m}$, $32-37 \mathrm{~kW} \mathrm{~m}^{2}, 30-31 \mathrm{~kW} \mathrm{~m}^{2}$, respectively. 
Smouldering spread rates are measured in the range from $3 \mathrm{~mm} \mathrm{~min}^{-1}$ to $25 \mathrm{~mm} \mathrm{~min}^{-1}$ and found to be a strong function of the heat flux and depth of the smoulder front from the free surface. Due to significant variability in the measurements, there is no clear effect of the effect of sample size on the spread rate. However, it is observed that the $50 \mathrm{~mm}$ samples consistently show lower spread rates for a given heat flux than the $100 \mathrm{~mm}$ or $140 \mathrm{~mm}$ samples.

The onset of smouldering ignition is observed at significantly lower heat fluxes than flaming (approximately $70-80 \%$ lower). This offers a route to initiate flaming fires from much weaker ignition sources by the mechanism of transition from smouldering to flaming. Critical heat fluxes for both smouldering and flaming ignition increase with the sample size, with smouldering ignition being significantly more sensitive to sample size than flaming ignition under the range studied. Since most standard testing is conducted a one single sample size on the order of $100 \mathrm{~mm}$, the observation reported here that the lowest flammability is observed for the largest samples could have implications for testing procedures and translation of small-scale testing to real applications in the built environment.

\section{Acknowledgements}

Financial support for this work was provided by the Engineering and Physical Sciences Research Council and International Fire Investigators and Consultants Ltd.

\section{References}

1. Bar Ilan A, Rein G, Fernandez Pello AC, Torero JL, Urban DL (2004) Forced forward smoldering experiments in microgravity. Exper Therm Fluid Sci 28(7):743-751. doi: 10.1016/j.expthermflusci.2003.12.012

2. Bar Ilan A, Rein G, Walther DC, Fernandez Pello AC, Torero JL, Urban DL (2004) The effect of buoyancy on opposed smoldering. Combust Sci Technol 176(12):20272055. doi:10.1080/00102200490514822

3. Torero JL, Fernandez Pello AC (1996) Forward smolder of polyurethane foam in a forced air flow. Combust Flame 106(1-2):89-109. doi:10.1016/0010-2180(95)00245-6

4. Walther DC, Anthenien RA, Fernandez Pello AC (2000) Smolder ignition of polyurethane foam: effect of oxygen concentration. Fire Saf J 34(4):343-359. doi:10.1016/ S0379-7112(00)00007-2

5. Anderson MK, Sleight RT, Torero JL (2000) Downward smolder of polyurethane foam: ignition signatures. Fire Saf J 35(2):131-147. doi:10.1016/S0379-7112(00)00016-3

6. Ohlemiller TJ (2002) SFPE fire protection handbook, chap 2-10: smouldering combustion, 3rd edn. National Fire Protection Association, Quincy, pp 2-201-2-210

7. Drysdale D (1998) An Introduction to fire dynamics, 2nd edn. Wiley, Chichester

8. Rein G (2009) Smouldering combustion phenomena in science and technology. Int Rev Chem Eng 1:3-18. http://hdl.handle.net/1842/2678

9. Torero JL (1992) Buoyancy effects on smoldering of polyurethane foam. $\mathrm{PhD}$ thesis, University of California, Berkeley. http://www.era.lib.ed.ac.uk/handle/1842/2134 
10. Ohlemiller TJ (1985) Modeling of smoldering combustion propagation. Prog Energy Combust Sci 11(4):277-310. doi:10.1016/0360-1285(85)90004-8

11. Krause U, Schmidt M (2000) Propagation of smouldering in dust deposits caused by glowing nests or embedded hot bodies. J Loss Prev Process Indus 13(3-5):319-326. doi:10.1016/S0950-4230(99)00031-5

12. Krause U, Schmidt M (2001) The influence of initial conditions on the propagation of smouldering fires in dust accumulations. J Loss Prev Process Indus 14(6):527-532. doi:10.1016/S0950-4230(01)00039-0

13. Schmidt M, Lohrer C, Krause U (2003) Self-ignition of dust at reduced volume fractions of ambient oxygen. J Loss Prev Process Indus 16(2):141-147. doi:10.1016/S09504230(02)00095-5

14. Schartel B, Bartholmai M, Knoll U (2005) Some comments on the use of cone calorimeter data. Polym Degrad Stab 88(3):540-547. doi:10.1016/j.polymdegradstab.2004. 12.016

15. Schartel B, Hull TR (2007) Development of fire-retarded materialsinterpretation of cone calorimeter data. Fire Mater 31:327-354. doi:10.1002/fam.949

16. Ritchie SJ, Steckler KD, Hamins A, Cleary TG, Yang JC, Kashiwagi T (1997) The effect of sample size on the heat release rate of charring materials. Fire Saf Sci 5:177188. doi:10.3801/IAFSS.FSS.5-177

17. Putzeys OM, Fernandez Pello AC, Rein G, Urban DL (2008) The piloted transition to flaming in smoldering fire retarded and non-fire retarded polyurethane foam. Fire Mater 32:485-499. doi:10.1002/fam.981

18. Putzeys O, Bar Ilan A, Rein G, Fernandez Pello AC, Urban DL (2007) The role of secondary char oxidation in the transition from smoldering to flaming. Proc Combust Inst 31(2):2669-2676. doi:10.1016/j.proci.2006.08.006

19. Gratkowski MT, Dembsey NA, Beyler CL (2006) Radiant smoldering ignition of plywood. Fire Saf J 41(6):427-443. doi:10.1016/j.firesaf.2006.03.006

20. Bustamante Valencia L, Rogaume T, Guillaume E, Rein G, Torero JL (2009) Analysis of principal gas products during combustion of polyether polyurethane foam at different irradiance levels. Fire Saf J 44(7):933-940. doi:10.1016/j.firesaf.2009.05.003

21. Torero JL (2008) SFPE fire protection handbook, chap 11, Flaming ignition of solid fuels, 4th edn. National Fire Protection Association, Quincy, pp 2-260-2-277

22. Palmer KN (1957) Smouldering combustion in dusts and firbous materials. Combust Flame 1:129-154. doi:10.1016/0010-2180(57)90041-X 